\title{
Fluvial erosion of inscriptions and petroglyphs at Siega Verde, Spain
}

\author{
Robert G. Bednarik* \\ International Federation of Rock Art Organizations (IFRAO), P.O. Box 216, Caulfield South, VIC 3162, Australia
}

\section{A R T I C C L E I}

\section{Article history:}

Received 10 October 2008

Received in revised form

8 May 2009

Accepted 23 June 2009

\section{Keywords:}

Schist

Weathering

Fluvial erosion

Inscription

Dating

Petroglyph

Siega Verde

Spain

\begin{abstract}
A B S T R A C T
Low-grade metamorphics such as slates and schists tend to be subjected to relatively rapid surface deterioration by both weathering and fluvial wear. If the rate at which such processes are effective on these relatively soft rocks could be calibrated through their effects on surfaces of known ages, this would provide a possibility of estimating the age of petroglyphs on similar facies and in similar environments. An attempt of quantifying these processes is presented, using the petroglyph site of Siega Verde in western Spain as an example. A series of dated inscriptions occurring at a site of zoomorphic petroglyphs provide the data to plot rock surface deterioration against time. The involvement of numerous variables prevents this method from providing much precision, but it is adequate to offer indications of order of magnitude of age. The zoomorphs at Siega Verde have been attributed to the Upper Palaeolithic, but this method suggests that most of the site's anthropic markings are under 200 years old. This finding is supported by several other factors, such as the degree of repatination of the supposedly Pleistocene petroglyphs, and the presence of a recent terrace predating these.
\end{abstract}

(c) 2009 Elsevier Ltd. All rights reserved.

\section{Introduction}

Siega Verde is a petroglyph site north-west of Ciudad Rodrigo, western Spain, extending some $1300 \mathrm{~m}$ along the left bank of the Río Agueda (Fig. 1). The site is located just west of the small town of Castillejo de Martin Viejo and about $50 \mathrm{~km}$ from the Côa petroglyph sites in Portugal (Bahn, 1995; Clottes, 1995; Bednarik, 1995). Like the Côa, the Agueda is a southern tributary of the Douro River, and like the Côa, it commences in the granite, gneiss and Silurian quartzite facies to the south, but then traverses low-grade metamorphics (Cambrian slates, schists and phyllites) before it drains into the Douro. The lower courses of both rivers were therefore scoured deeply into the topography, as the quartz cobbles and boulders of the uplands were rafted through soft-rock lower valleys.

The need to cross the deeply cut Agueda valley for access to several village communities to the west has led to the successive construction of bridges near Castillejo de Martin Viejo, which have fallen victim to the torrents of past major river floods. Superficially, the steep-sided Agueda valley in the vicinity of the Siega Verde site may appear relatively pristine, but numerous traces of structures bear witness to great investments of labour in the vicinity of the petroglyph site. Apart from the bridge (Fig. 2) in the site's centre

\footnotetext{
* Tel./fax: +61395230549.

E-mail address: auraweb@hotmail.com
}

and impressive ruins of a mill, there are remnants of former bridge supports close to it. Several hundred metres upstream, a series of four massive dry-stone piers of a former bridge survive, as well as systems of substantial stonewalls. The remains of various structures can also be found downstream of the present bridge. Clearly, this section of the Agueda valley, although not actually settled, has seen considerable human activity over recent centuries, and it is evident that rock markings coincide spatially with such centres of economic activity - as they do in the Côa valley.

The rock art corpus comprises several hundred figures (reportedly about 560), of which only in the order of sixty are clearly discernible. It occurs on soft schist blocks and outcrops that have been, and continue to be, sculptured by the coarse angular quartz grains of the river sand. The river floods frequently to a depth of 6-8 $\mathrm{m}$, and all petroglyphs are located within this flood zone. As in the Côa valley, the petroglyphs were known to residents for as long as they have existed, and villagers from Castillejo de Martin Viejo have reported that the rock art was 'made by shepherds whiling away the time'; they 'had a good laugh when archaeologists told them the art was Palaeolithic' (Hansen, 1997), after archaeologists 'discovered' in 1988 what had always been known to the villagers (de Balbín et al., 1991; de Balbín and Alcolea, 1994; Bahn and Vertut, 1997: 130). Besides the mostly pounded animal images, none of which resembles Franco-Cantabrian rock or portable art of the Palaeolithic (which is generally incised), there are also numerous inscriptions at the site, many of them with dates. A brief visit by the 


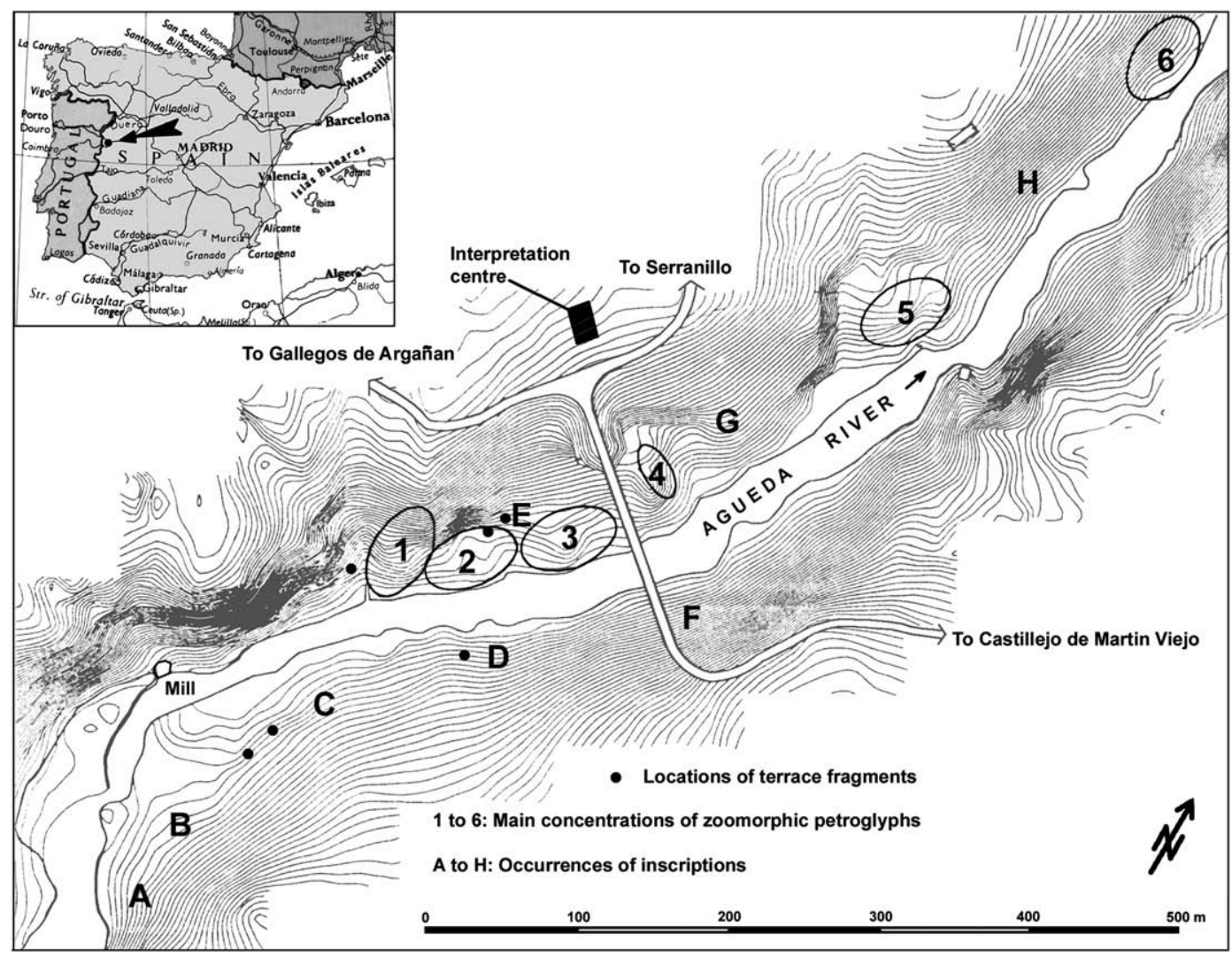

Fig. 1. Map of the Siega Verde site near Ciudad Rodrigo, western Spain; contour intervals at $1 \mathrm{~m}$.

author in September 1998 provided three clues to the age of the rock art:

1. One of the central piers of the bridge had been erected so that its base partly conceals a petroglyph. This proves conclusively that at least some of the site's petroglyphs must predate the time when the structure was erected, in 1925.

2. The base of the same support pier, about $2.5 \mathrm{~m}$ above the normal water level, had been built of the same grey schist it stands on. It had since 1925 been subjected to bombardment by

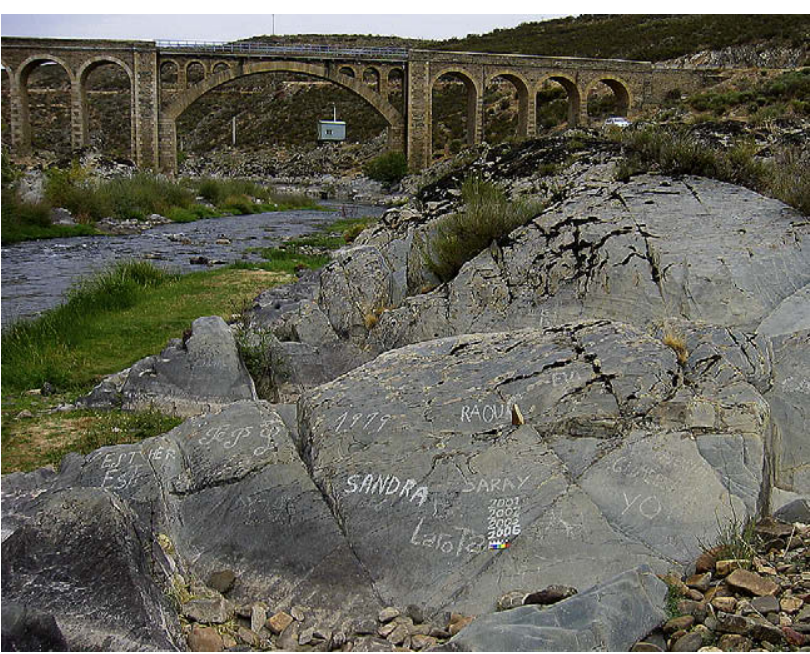

Fig. 2. The Siega Verde bridge, looking north, with some dated inscriptions. coarse and sharp-grained quartz sand every time the river flooded. In the course of 72 years, this had resulted in a surface retreat of up to $30 \mathrm{~mm}$ in the lowest structural blocks, indicating the schist's susceptibility to fluvial abrasion.

3. Crevices and recesses at the site provide ample evidence of the former presence of an extensive alluvial terrace of very coarsegrained composition (mostly cobble to boulder clasts), in the form of many firmly lodged, small remnants at elevations up to $7-8 \mathrm{~m}$ above the river.

The significance of the last-mentioned factor is that this former terrace deposit must predate any of the rock art. Both its accumulation and eventual degradation would have had dramatic effects on the valley's topography, and would have erased any surface features within the flood zone. All of the rocks now bearing petroglyphs were submerged by this terrace deposit, therefore it provides a secure terminus post quem for the Siega Verde petroglyphs. At a location about $5 \mathrm{~m}$ above the river, $60-70 \mathrm{~m}$ upstream of the bridge, the author recovered from one of these small terrace residues in a deep recess a 10-cm-large pottery shard in 1998. It occurred just above some petroglyphs and is from a vessel made with a pottery wheel. Probably of the Roman period (M. Simões de Abreu, pers. comm.), it is water-worn and had been transported with sediment for some distance; so there can be no doubt that the former terrace deposit must be well under 2000 years old. It follows that all of the site's petroglyphs must be more recent again.

\section{Methods}

This narrows down the possible age range of the rock art, but a better and perhaps more generically applicable chronological resolution appeared feasible by focusing on the fluvial erosion of 
the schist and its repatination patterns. In September 2006 the site was subjected to detailed examination involving three especially adapted microscopes.

There are over a thousand inscriptions within a kilometre or so of the site's centre and nearly all of them occur in the flood zone also occupied by the petroglyphs. Inscribed dates show similar degrees of wear by suspended particles. Plotting of the degree of wear evident in these inscriptions against their age demanded the identification and determination of key variables expressing the progressive deterioration of the grooves. It begins with weathering ('fading', first 10\%), followed by blunting of edges (next 10\%), then the gradual obliteration of impact pits, leading to progressive asymmetry in groove section, development of micro-fluting (an advanced form of asymmetry), reduction of groove depth (indicative of over $70 \%$ wear), and finally the obliteration of the groove (100\%), at which point any remaining surface depressions would no longer be identifiable as anthropic. If these factors are to be a function of time, it is essential that progressive linear equivalence be attempted. Groove asymmetry, determined by direction of water flow, is perhaps the most important of them, and it is also the most readily quantified. It was also apparent that this Degree of Erasure needed to be correlated with other variables, particularly the elevation above the thalweg or the river's low water level; the orientation relative to water flow; the depth of grooves; and the elevation above the nearest channel bed (there are numerous subsidiary channels, most only active during flooding, and these may be up to several metres above the valley's true thalweg) and its geometry.

Because of the inherent strata of the Siega Verde schist, flat panels are frequently of identical orientation, which effectively controls for one variable, and their relative exposure to sand blasting is then essentially a function of the remaining variables. Nearly all inscriptions (and petroglyphs) were made by direct percussion with hammerstones, and as the schist is homogenous, there is little variation in groove depths; they fall mostly between 3 and $6 \mathrm{~mm}$. Since all variables, including age of some of the inscriptions, are empirically available, such a framework could predict the approximate antiquity of any undated inscription-or for that matter, any petroglyph-at this site.

Elevation of datable inscriptions above the nearest riverbed was plotted against Degree of Erasure, as determined by field microscopy (Fig. 3). The desired calibration curve was then established by plotting Degree of Erasure against known ages (Fig. 4). No specific patterning is obvious in Fig. 3, but Fig. 4 provides a useful calibration curve for realistic age range. The granulometric characteristics

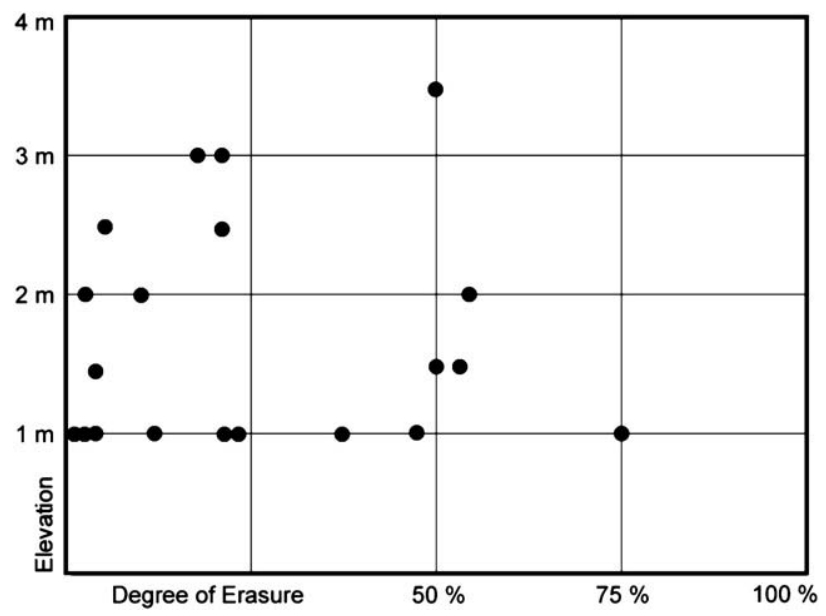

Fig. 3. The elevation of dated inscriptions plotted against their Degree of Erasure.

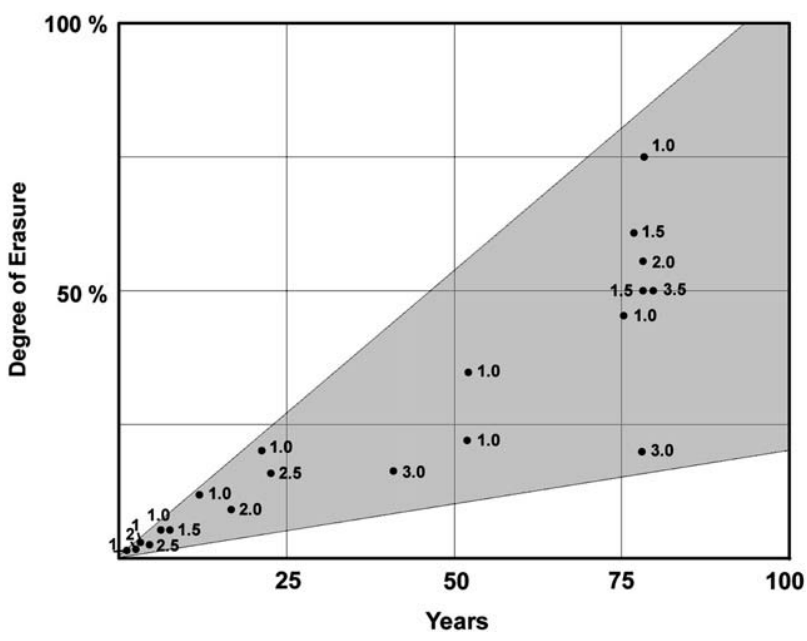

Fig. 4. Dated inscriptions plotted by age against Degree of Erasure, indicating the apparent zone of distribution. Elevation in $\mathrm{m}$ above low water level is indicated.

of the river sand were also determined, as were details of accretionary mineral skins and rock weathering characteristics of the schist.

\section{Observations}

The rapid surface weathering ('fading') is readily apparent from a group of four dates from 2000 to 2006 , possibly engraved by the same person to commemorate repeated visits, occurring as an aligned group roughly opposite petroglyph panel 14 (Figs 2 and 5).

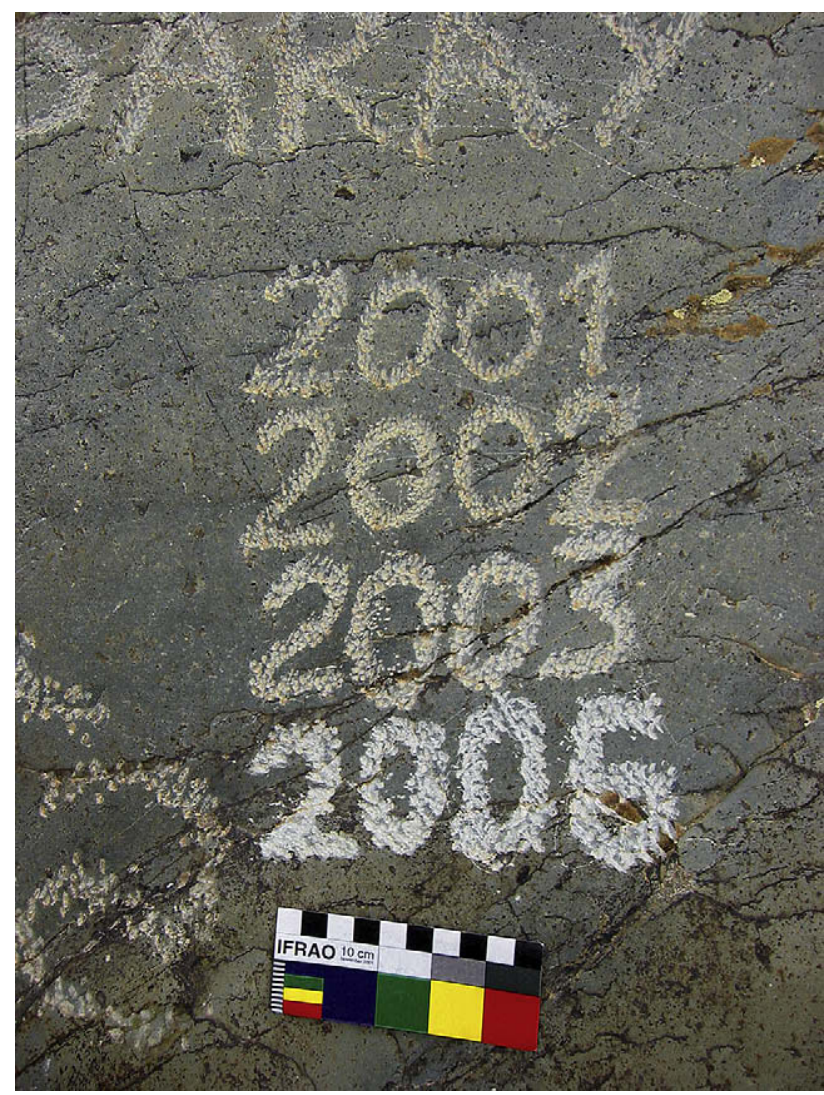

Fig. 5. Series of engraved dates, possibly the work of one person, showing the rapid darkening or 'patination' inherent in the rock (photograph taken September 2006, scale in $\mathrm{cm}$ ) 
At the pool immediately upstream of the mill-ruin occur several concentrations of inscriptions, one of which, just $1 \mathrm{~m}$ above the normal water level, includes the date of 1954. This date shows $20-25 \%$ wear. Together with other inscriptions this group occurs on a large exfoliation scar, the result of the removal of a thin tabular panel, which is weakly patinated and contrasts with the blackish patinated earlier surface, still covering much of the panel (Fig. 6). The most prominent words on the exfoliation surface are 'JAVIER SIERRO MUNOZ PA'. This probably cohesive composition is significantly older than the 1954 inscription below it. Based on the roughly $40-50 \%$ abrasion it might well date from about 1925, i.e. the time of the bridge's construction. Individual percussion pits remain visible but only on the upstream side, where they are emphasized by black accretionary deposits. On the downstream side of every vertical stroke (which has been subjected to more intensive sand bombardment), pits are no longer visible due to the stronger effects of the fluvial erosion by the sand. Fig. 7 illustrates also that this sand scouring has resulted in the development of horizontal fluting in the micro-topography of the surfaces most affected. This pattern of fluvial wear is particularly evident on the vertical strokes of some inscriptions and has resulted in a typical groove profile: on the right margin of the grooves, which is the direction from which the water flow approaches, the original edge of the groove and individual impact marks remain recognizable, but, as shown on the microphotograph (Fig. 8), the left groove margins have become entirely erased.

Among the several other panels with pounded inscriptions in the vicinity, special attention was given to one located $6 \mathrm{~m}$ upslope, at an elevation of 2.5-3.7 $\mathrm{m}$ above the normal water level (Fig. 9). The upper inscriptions are poorly decipherable, but there is a distinctive 'MB' at its base, and to the right of these letters occurs an abraded ' $M$ '. This is one of the few engraved inscriptions of the entire site; percussion produced nearly all others (Fig. 10). It is clearly much more recent than the pounded 'MB' inscription on a similar level and nearby; it is shallower and shows limited fluvial wear by suspended particles, and it is free of microflora. Its age is unknown, but can safely be assumed to be only a few decades. Nevertheless, it has experienced considerable microscopic surface modification and almost complete obliteration of tool striations.

A nearby inscription 'MA' (Fig. 11), at nearly $3 \mathrm{~m}$ above the river, includes no date, but is traversed by four protruding quartz veins permitting microerosion analysis (Bednarik, 1992). Where the veins

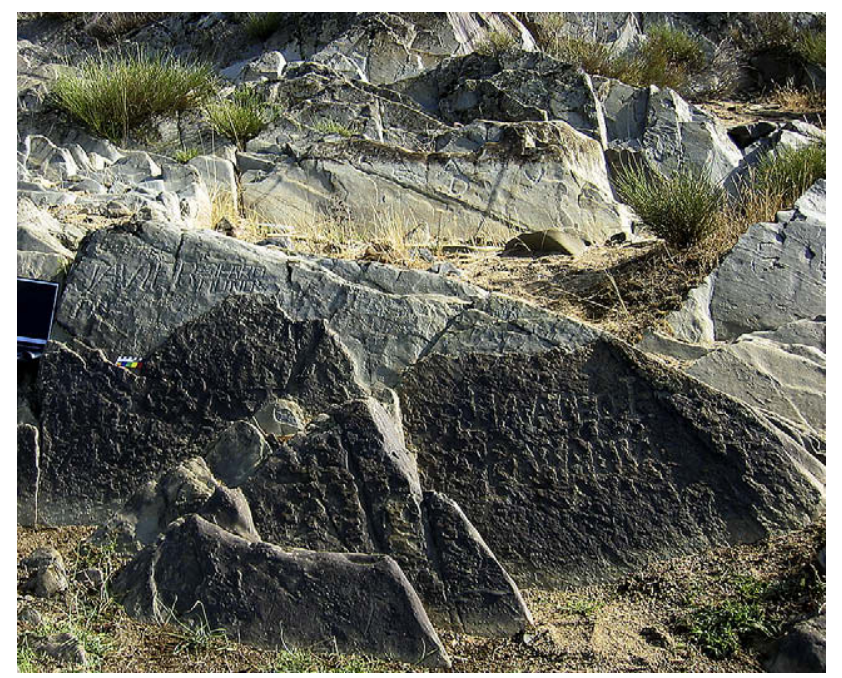

Fig. 6. Concentration of several Siega Verde inscriptions being subjected to digital microscopy.

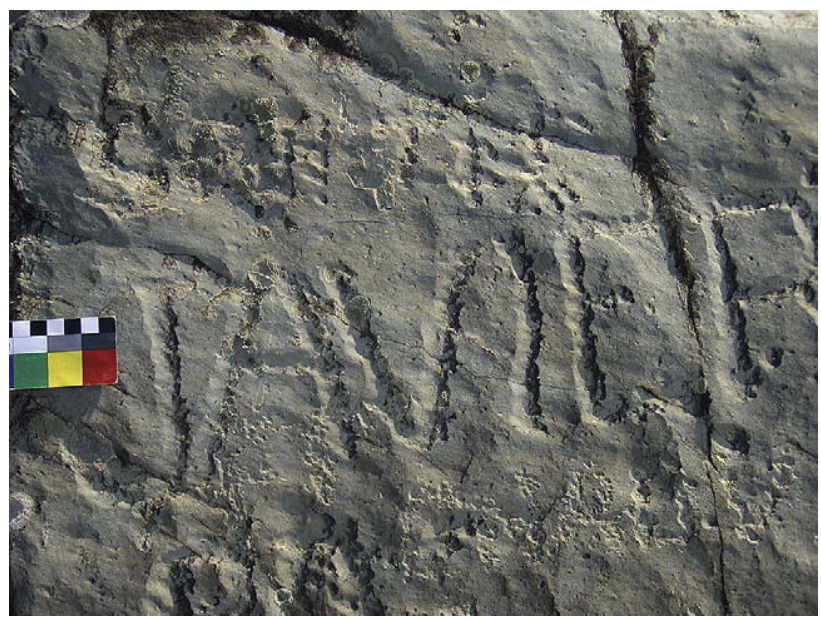

Fig. 7. Siega Verde inscription showing fluted erosion patterns; scale in $\mathrm{cm}$.

have been fractured, micro-wane widths were obtained (mostly from the left stroke of the ' $A$ '), suggesting an age of about 80 years (applying the Vila Real calibration curve from northern Portugal, which was obtained from Roman bridges and an inscription; Bednarik, 2003). This inscription occurs on a near-vertical panel exposed to moderate sand flow and shows about 20\% wear. Another, similarly exposed inscription nearby, reading 'JOR'-'GE' is of $30 \%$ wear (Fig. 12).

One of the largest concentrations of inscriptions occurs at the bridge, where most of them can be spatially related to the bridge construction. Significant quantities of schist have been quarried near the bridge piers, either as building material or to facilitate the placement of scaffolding and other equipment. This work has resulted in the creation of large flat panels, exposed around the time of the building of the imposing structure. Therefore it can be assumed that these inscriptions either date from 1925 or are more recent. The older specimens are very likely the work of bridge construction crewmembers, others were clearly added later.

In plotting the inscriptions of known, or approximately known ages (Fig. 4) it is evident that height above base of subsidiary

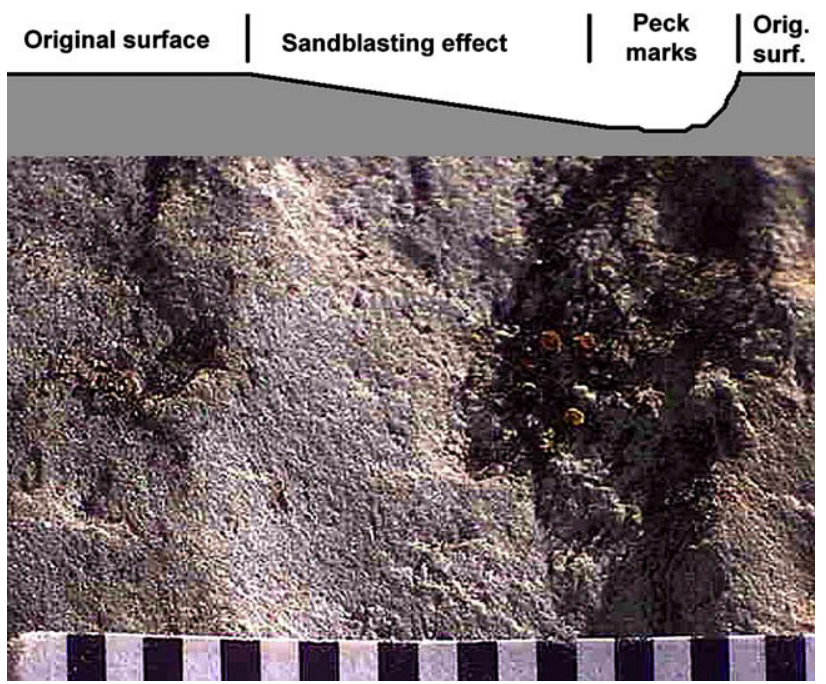

Fig. 8. Microphotograph of a groove, the right vertical stroke of the $U$ in the inscription 'MUNOZ', showing the heavy modification from being bombarded by quartz sand during floods; the water flow is from right to left. Note the microflora on the lee side. The section, on top, indicates the progressive erasure of the inscription. Scale in $\mathrm{mm}$. 


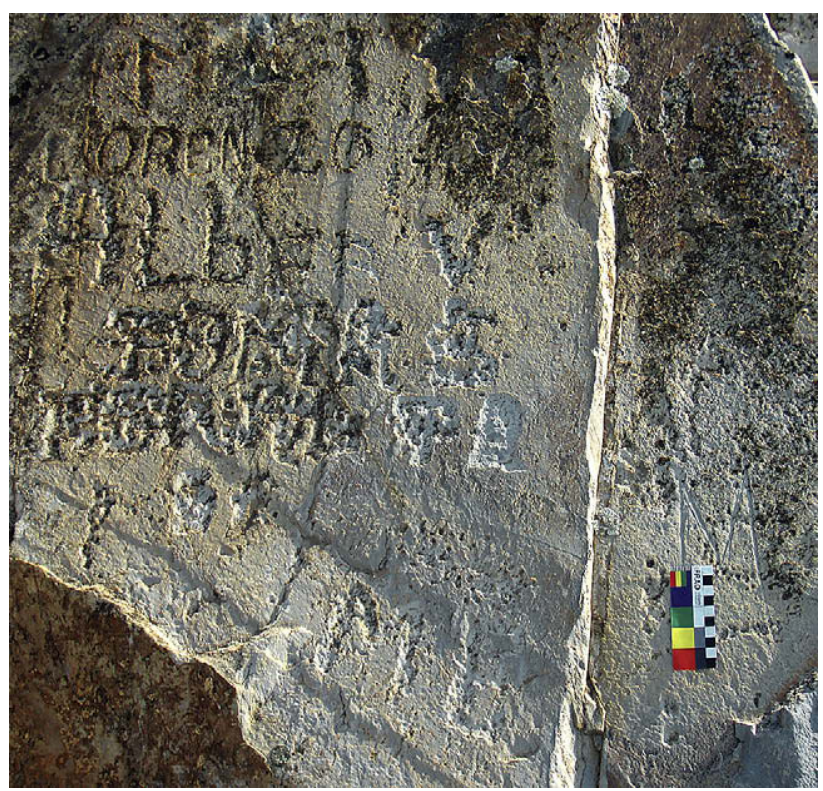

Fig. 9. Near-vertical panel with inscriptions, note abraded 'M' above scale, and 'MB' to the left of it; scale in $\mathrm{cm}$.

channel bed is of greater effect than absolute elevation above the river. Values appear rather scattered because of predictable irregularities in local conditions (orientation, rock topography, riverbed geometry, elevation relative to base of nearest subsidiary bed channel), which is in part due to recorded elevations referring to the river rather than nearest channel floor, Nevertheless, a trend is evident which shows that after 150-200 years of exposure to erosion, an inscription of up to $5 \mathrm{~mm}$ depth would become unintelligible or erased in any location subjected to this process. Markings close to the base of a 'subsidiary thalweg' might only survive for a few decades, and should be regarded as lying outside the detectable range in this exercise (i.e. be above the shaded area in Fig. 4).

\section{Fluvial abrasion}

It is important to distinguish between the erosive function of suspended sediment, which is related to elevation above the

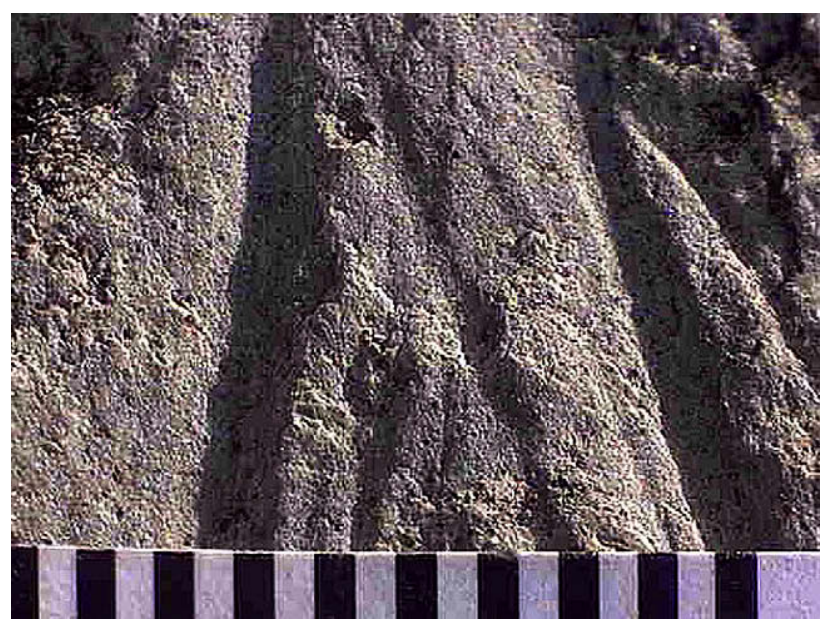

Fig. 10. Microphotograph of part of the abraded 'M' inscription, showing degree of wear and faintness of tool striations; scale in $\mathrm{mm}$.

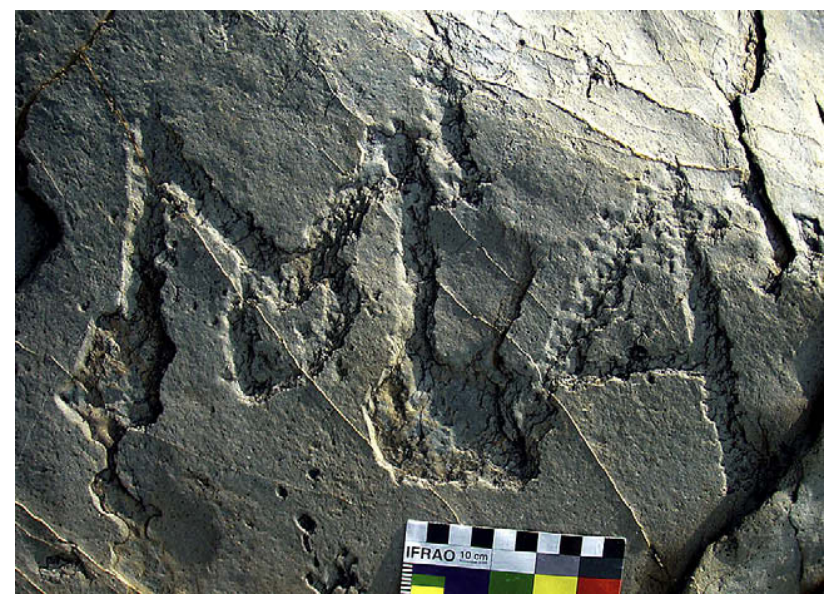

Fig. 11. 'MA' inscriptions with four protruding quartz veins that provided microerosion data; scale in $\mathrm{cm}$.

nearest channel bed and has limited effect higher than 5-6 $\mathrm{m}$ above the river; and the inherited fluvial wear from the time the most recent terrace was mobilized, perhaps a few centuries ago. The latter is indiscriminate and can be found at heights of up to $8 \mathrm{~m}$, whereas recent sand abrasion is most developed at lower elevations, although it can be active throughout the water column.

The remnants of the terrace(s) are dominated by cobbles, especially well-rounded quartz detritus, even of boulder fraction up to a metre in size. Where they have survived best, in sheltered crevices and bedrock joints, its components appear tightly packed and well consolidated (Fig. 13). The effect of the transport of this mass on the bedrock is illustrated at locations that experienced high kinetic impact: the diagonally orientated schist plates have been battered to stumps, plucking occurred and outcrops have been fluted extensively by suspended particles (Fig. 14). Cavitation by pothole formation is also found in the zone affected, which extends up to about $5 \mathrm{~m}$ from the low water level, with greatest effects observed in its lower half. It is impossible for petroglyphs to survive for any great time span on such soft rock in this environment, and it is entirely futile to expect to find any of an age greater than the time of the terrace deposition, or of its removal, at any elevation of $<6-8 \mathrm{~m}$ above the river. The terrace (or the terraces, if there were several successive deposits, or cut-in-terraces or nested terraces; Easterbrook, 1999: 172-178) appears to have been a fill terrace

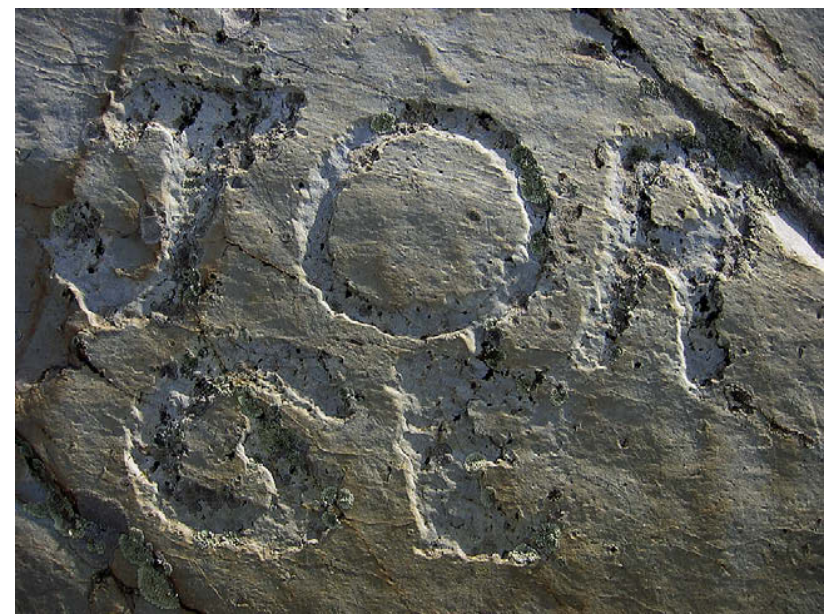

Fig. 12. Inscription showing Degree of Erasure of about $30 \%$. 


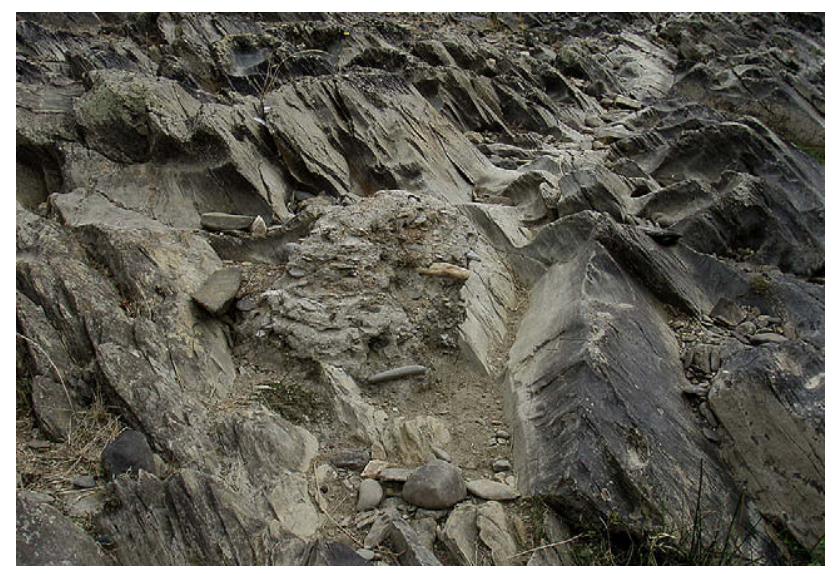

Fig. 13. Eroding remnant of very late Holocene terrace deposit at the Siega Verde rock art site; note the deeply scoured bedrock.

rather than a strath terrace (Montgomery, 2004), although this is not certain in view of the small size of most remnants, the lack of dating and the inherently stochastic nature of the formation processes (Snyder et al., 2003).

While bedrock channel incision may occur relatively rapidly (Whipple et al., 2000a; Hartshorn et al., 2002; Stock et al., 2005; Reusser et al., 2006), it is not a primary concern in clarifying the chronology of the Siege Verde features. Of greater importance than plucking or bedload abrasion is the impact of suspended-load abrasion (Alexander, 1932; Foley, 1980; cf. Sklar and Dietrich, 1998; Snyder et al., 2000). The inscriptions are progressively worn by abrasion processes that operate at a sub-millimetre scale, and abrasion by suspended particles is therefore highly likely at the site. The sand at Siega Verde ranges from $5 \mathrm{~mm}$ ('small pebble' fraction) down, but the component of $<0.63 \mathrm{~mm}$ is small and fine fractions are almost absent. The sand consists largely of 'coarse sand' granulometric fraction, and relatively angular quartz grains predominate. In some locations, for instance among the petroglyphs just below the bridge, recent sand deposits are very well sorted, consisting almost entirely of very coarse quartz sand (Figs 15 and 16). A typical sample comprises (numerically) $86.3 \%$ quartz grains (ranging from well rounded to highly angular), 4.7\% feldspar and the remaining $9.0 \%$ are made up by numerous minerals (including mica, staurolite, tourmaline, haematite and greywacke).

Hartshorn et al. (2002) have shown that small grains of diameter $d \leq 2 \mathrm{~mm}$ can travel in significant numbers up to a flow depth of 4-6 $\mathrm{m}$ in turbulent suspension and be responsible for significant bedrock abrasion (Hartshorn et al., 2002: Fig. 3A), in particular if a soft lithology is exposed. Schist has been shown to be up to 2 orders of magnitude more erodible than quartzite or granite (Attal and Lavé, 2006: 156, 159). The largest grains in suspension have considerable inertia and preferentially strike obstructions on the upstream side, whereas intermediate size particles may follow gently curved streamlines upstream of obstructions, but impact on their lee side where shedding vortices produce sharply curved streamlines (Whipple et al., 2000b). The smallest particles tend to follow streamlines faithfully and have negligible impact on the rock surface. Consequently, the abundant coarse sand to small pebble fraction transported during floods at Siega Verde certainly causes degradation on both upstream and downstream surfaces of obstructions.

In considering the abrasive action of a single saltating quartz grain, the precise kinetic conditions of the process are relevant. The contact area of an angular grain with the surface that it impacts is smaller than the contact area of a similar rounded grain with

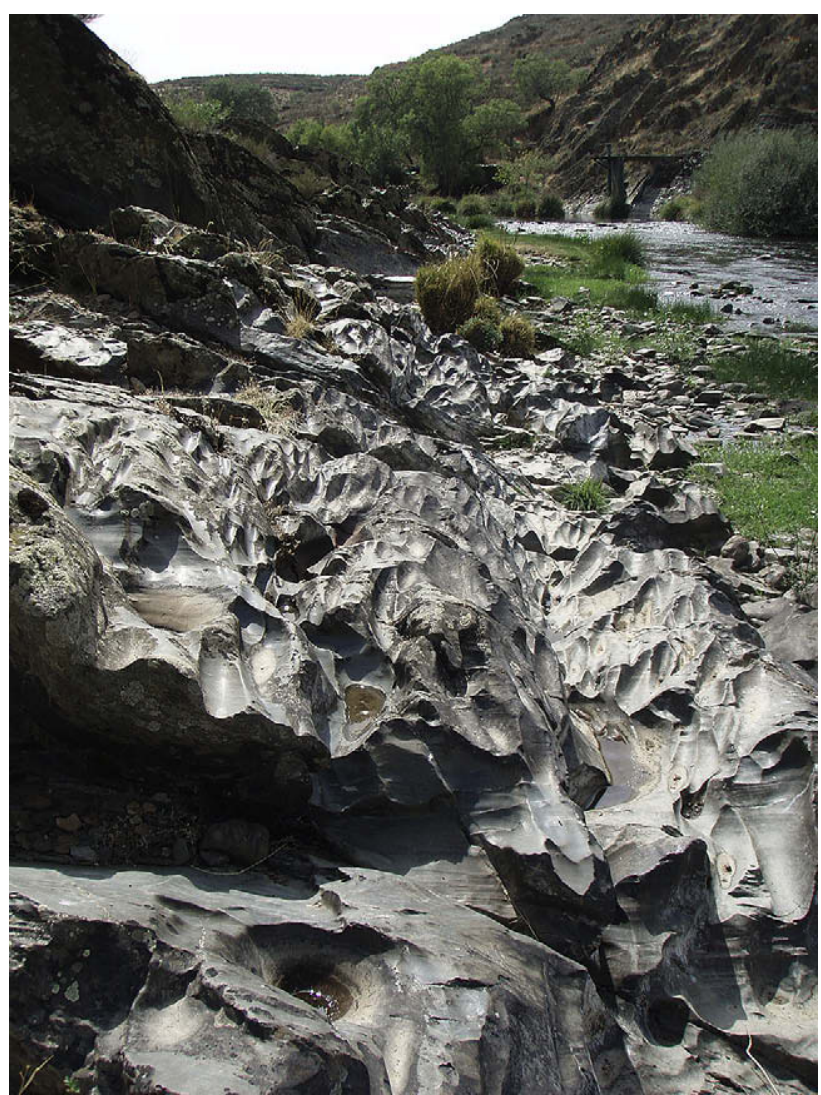

Fig. 14. Schist bedrock sculpted by the transport of quartz detritus of most grain sizes at the Siega Verde petroglyph site, looking south; note the pothole in the foreground.

a similar surface, causing greater damage. Each quartz grain, of hardness 7 on Mohs Scale, scores the very soft rock surface of the schist (hardness 3)-which is undergoing rapid weathering by hydration - under hydraulic pressure (water column up to $8 \mathrm{~m}$ ) and velocity (Graf, 1977; Anderson et al., 1994). Angular particles impacting softer ductile material can potentially scratch it, with a maximum material removal for impact angles of 30 degrees (Finnie, 1980). The abrasive effectiveness of the coarse angular, mostly quartzitic sand in this dynamic environment is therefore very high: the soft schist is correspondingly sculptured and cumulative wear becomes readily visible macroscopically. This is very evident not only at the base of the bridge piers, but also on some of the perhaps earliest remaining inscriptions.

\section{Petroglyphs}

The surviving petroglyphs at Siega Verde are of considerable technological and stylistic diversity. The majority are pounded (rather than pecked), while the engraved motifs tend to be small and hard to see. Only one of the relatively large animal figures is made by abrasion, the southernmost on the tourist circuit (on petroglyph panel 14). A number of smaller figures are incised, including one very tiny 'goat head' which was made with a metal implement but is patinated fully. Finally, there are a small number of non-iconographic incised motifs of the 'filiform' type (bundles of sub-parallel shallow and fine incisions). It is particularly important that some of the large pounded animal motifs are clearly superimposed over such filiform motifs, and while the former are only lightly repatinated, the latter are completely covered by the very dark deposits and are much older than the zoomorphs (Fig. 17). 


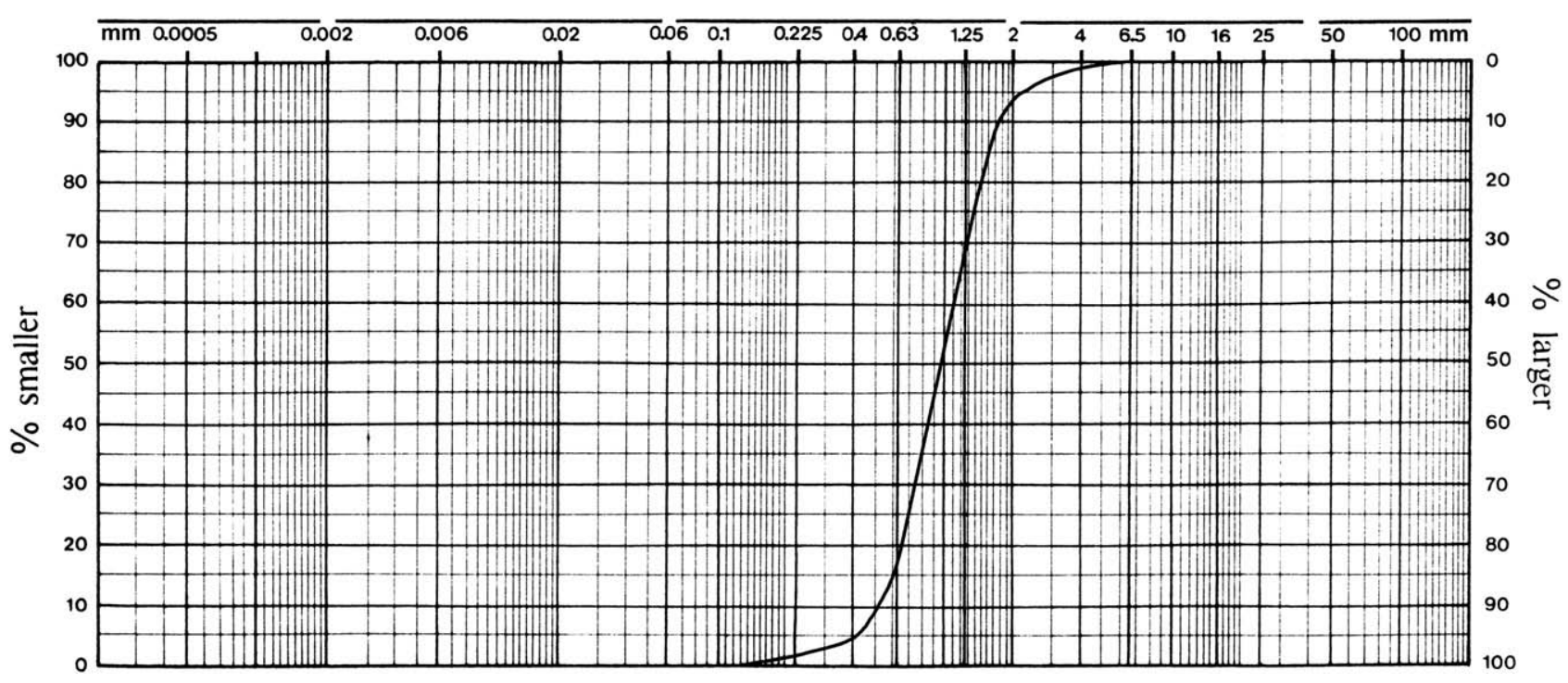

Fig. 15. Typical grainsize distribution of the river sand at Siega Verde, showing a predominance of coarse sand; $82.87 \%$ is $>0.63 \mathrm{~mm}$.

That alone suffices to refute the Upper Palaeolithic antiquity of the zoomorphs. The filiforms occur at elevations of 6-7 $\mathrm{m}$ above the river and have therefore experienced negligible if any abrasion by suspended particles. They appear to have been produced by metal points, but this has not been conclusively established because of their deep weathering and accretions. Similar filiform patterns occur at other sites in the region where they are attributed to the Iron Age (e.g. Vermelhosa; de Abreu et al., 2000). Comparative colorimetry (Bednarik, 2009) suggests that the filiform patterns are in the order of twenty times older than the superimposed zoomorphs.

However, the principal indicators of the age of this assemblage of petroglyphs relate to context and geology. The age of a few images next to the central western bridge pier is determined by the age of the bridge, because these are either partly concealed by the structure, or access to them is so limited that they could not possibly have been executed after the construction of the bridge. These were created on the prepared rock platform of the pier, and therefore have to date from the construction period. This

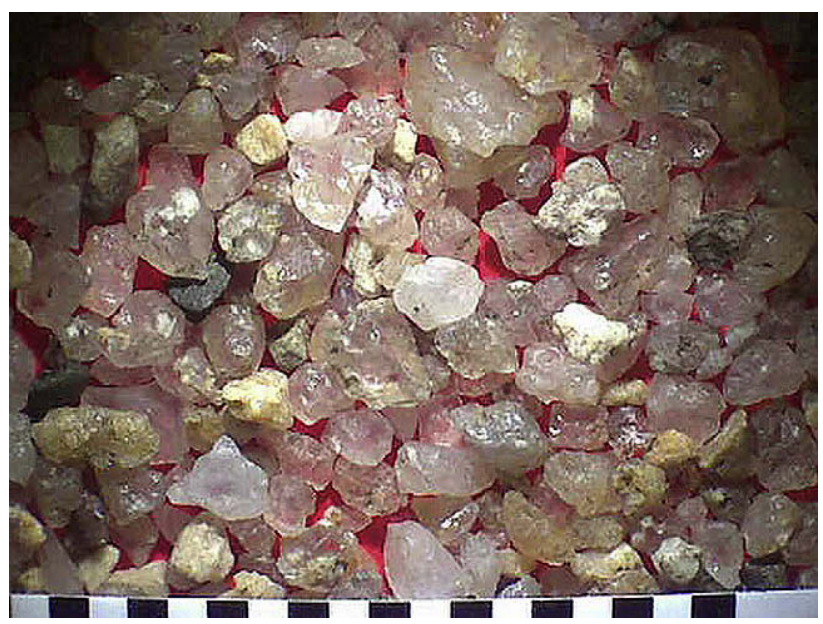

Fig. 16. River sand among Siega Verde petroglyphs, comprised mostly of angular quartz grains; scale in $\mathrm{mm}$. establishes unambiguously that at least some of the site's zoomorph petroglyphs were produced around 1925.

The large abraded figure of panel 14, occurring between 2.5 and $3.0 \mathrm{~m}$ above the normal water level, was microscopically examined to estimate the level of subsequent erosion. The groove is generally U-shaped and averages around $5 \mathrm{~mm}$ width. Striations have barely survived, but some remain visible and they suggest that the zoomorph was created with a stone tool. However, they also indicate that the figure, exposed as it was to significant fluvial wear, cannot be older than the inscriptions of the early 20th century (cf. similar condition of inscription ' $M$ ' above, at similar elevation). In the absence of direct dating evidence from most of the animal figures, the level of fluvial erosion is perhaps the safest indicator of relative antiquity.

A petroglyph depicting a bovid head is located on a vertical panel upstream of the bridge, between $1 \mathrm{~m}$ and $2 \mathrm{~m}$ above the present normal river level. It is fully exposed to the oncoming water flow during inundation episodes and shows typical erosion wear. The degree of this wear is slightly greater in the lower part of the image, but overall ranges from $20 \%$ to $30 \%$ at the most, using the same empirical criteria as previously applied to the inscriptions (Fig. 18). Taking into consideration the exposure and relative location of the panel, this implies an age of the petroglyph roughly corresponding to the inscription '1954' mentioned above. On the basis of Fig. 4 the petroglyph could be between 25 and 100 years old, but the level of exposure would point to the lower part of that range. Yet some archaeologists have attributed this figure to the Upper Palaeolithic, on the basis that it is claimed to depict an aurochs and that it is executed in a 'Palaeolithic style'. The same kind of reasoning has been applied in the nearby Côa valley, and yet the bovid images clearly resemble the cattle of the region more than aurochs. That species may not even have occurred in the region during the final Pleistocene stadial; it is more typical of a Holocene fauna and probably occurred up to historical times.

Indeed, some archaeologists apparently consider all zoomorphs at the Siega Verde site as being of the Late Pleistocene, despite the obvious lack of significant repatination or fluvial wear in most of them. Moreover, there is not a single depiction of a species that did not exist in the region during recent centuries, and this applies also to the thousands of other Iberian petroglyphs at open-air schist sites that have been attributed to the Upper Palaeolithic 


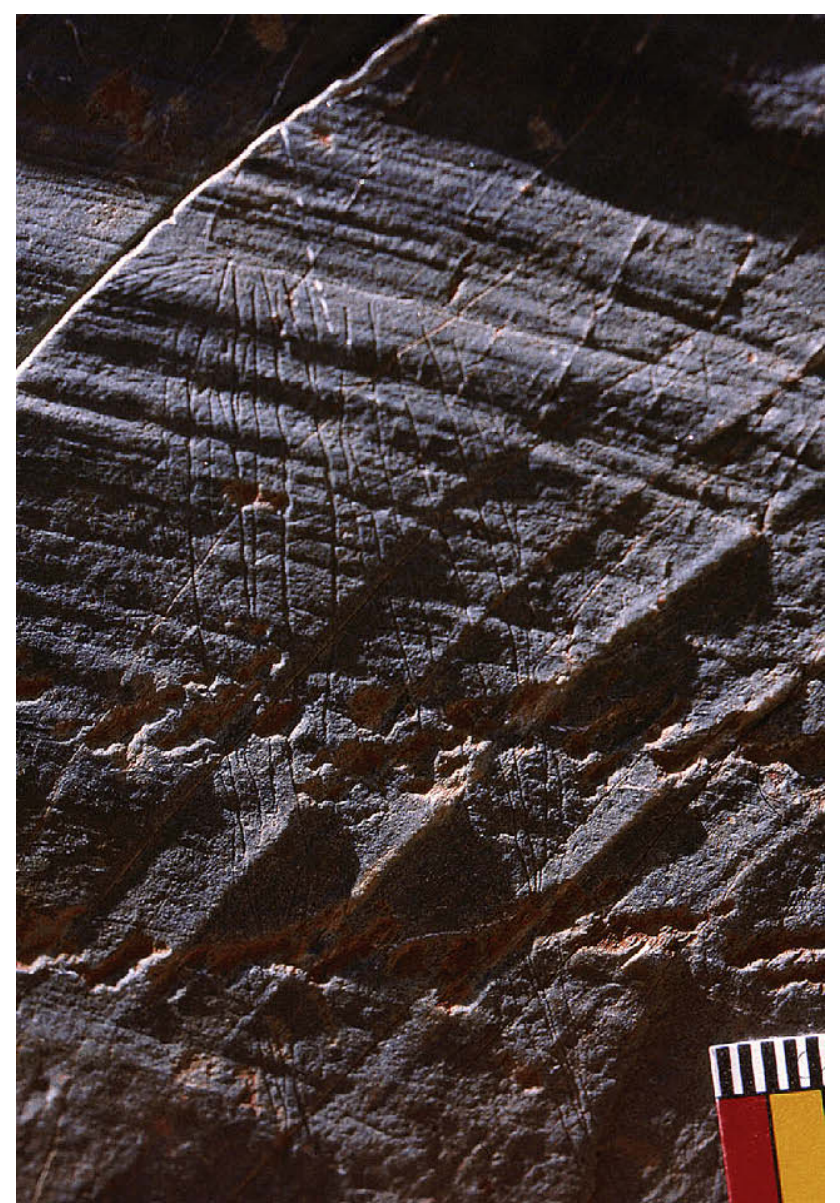

Fig. 17. Part of a pounded zoomorph (equine), weakly repatinated, superimposed over earlier, completely repatinated single-incision markings (filiform); scale in mm.

(Aubry et al., 1997; Bahn, 1985; Jorge et al., 1981; Martín Santamaría and Moure Romanillo, 1981; Martínez, 1986/87; Ripóll Lopez and Muncio González, 1994; Ripoll, 1997; Zilhão, 1995; Zilhão et al., 1997). The animal figures of all these sites are typically of horses

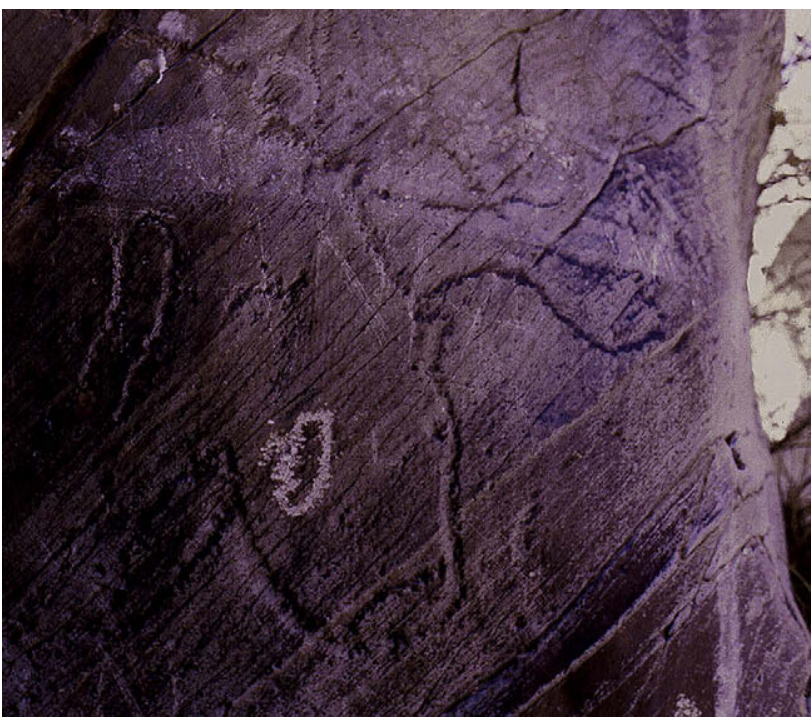

Fig. 18. Percussion petroglyph, a zoomorph claimed to depict an aurochs, on a vertical panel fully exposed to the water flow. The figure's Degree of Erasure places it firmly in the 20th century and it may depict the currently favoured cattle breed of the region. and Spanish fighting bulls, the latter with their characteristically curved, forward-pointing horns. Sometimes there are also a few cervids or caprids. Most of them do not resemble Pleistocene zoomorphs stylistically, and technologically none do. In the case of Siega Verde, a dog-like quadruped occurs, and a zoomorph sometimes defined as a feline, although it much more resembles a ferret or weasel. It has even been claimed that there are depictions of a rhinoceros and a megaloceros at Siega Verde, but no such images exist there. Nor is there any depiction of typically Pleistocene fauna at any of these Iberian schist sites. Finally, there are no unambiguous geometric motifs of the type usually called 'signs' to be found at them, yet these are the most characteristic, most common and distinctive of the Palaeolithic designs in cave sites attributed to the Upper Palaeolithic art traditions. Both extinct animal depictions and Palaeolithic 'signs' are numerous in Spanish cave sites, in fact the latter occur in great numbers in various parts of Spain (Casado Lopez, 1977).

\section{Conclusions}

Based on demonstrated rates of fluvial erosion of the soft, lowgrade metamorphics the Siega Verde site consists of, it is unlikely that any anthropic rock marking at less then $6 \mathrm{~m}$ above the normal water level of the Agueda River could survive more than 200 years. The calibration data so far secured (Fig. 4) further imply that an antiquity in excess of 400 years can safely be excluded from consideration. It was attempted to quantify erosion by a detailed survey of all markings of known sidereal age (inscriptions of dates, activity marks made by bridge builders and structures of known ages), but the result remains subject to some qualifications. The degree of uncertainty attached to these findings is related to two principal factors: the potential variability in water flow through time, and the changes to current patterns (direction and velocity) because of variations in local topography through time. A secure terminus post quem age for all rock markings is provided by the age of the most recent terrace, which is post-Roman. These findings coincide with the clear presence of incised filiform petroglyphs greatly predating the supposedly Upper Palaeolithic zoomorphs; with a lack of significant repatination on most of these images; with an absence of distinct Palaeolithic style and technological conventions (proven Upper Palaeolithic engravings are typically abraded or incised); and with a lack of depicted species not present in the region today.

On this basis the author concurs with the local people of nearby Castillejo de Martin Viejo that the rock art of Siega Verde is the work of recent artists, including perhaps stone masons, dating mostly of the early 20th century. The probability that any petroglyphs could have survived at this site, at locations of less than $6 \mathrm{~m}$ above the river, from any pre-Historic times is for all practical purposes nil.

\section{Acknowledgment}

The author thanks three anonymous JAS reviewers for their insightful and highly constructive improvements of the text.

\section{References}

de Abreu, M.S., Arcà, A., Jaffe, L., Fossati, A., 2000. As gravuras rupestres da Idade do Ferro no Vale de Vermelhosa (Douro - Parque Arqueológico do Vale do Côa). In: Notícia preliminar. Proto-História da Península Ibérica, Actas do 3. Congresso de Arqueologia Peninsular, vol. 5. ADECAP, Porto. 403-406.

Alexander, H.S., 1932. Pothole erosion. Journal of Geology 40, 307-335.

Anderson, R.S., Dick, G.S., Densmore, A., 1994. Sediment fluxes from model and real bedrock-channeled catchments: responses to baselevel, knickpoint and channel network evolution. Geological Society of America Abstracts with Programs 26 (7), 238-239. 
Attal, M., Lavé, J., 2006. Changes of bedload characteristics along the Marsyandi River. In: Willett, S.D., Hovius, N., Brandon, M.T., Fisher, D.M. (Eds.), Tectonics, Climate, and Landscape Evolution. Special Paper 398. The Geological Society of America, pp. 151-171.

Aubry, T., Carvalho, A.F., Zilhão, J., 1997. Arqueologia: Salto do Boi - Cardina I. Arte rupestre e pré-história do Vale do Côa (trabalhos de 1995-96). Relatório científico ao Governo da República Portuguesa, Lisbon, pp. 1-23.

Bahn, P.G., 1985. Ice Age drawings on open rock faces in the Pyrenees. Nature 313, 530-531.

Bahn, P.G., 1995. Cave art without the caves. Antiquity 69, 231-237.

Bahn, P.G., Vertut, J., 1997. Journey Through the Ice Age. Weidenfeld and Nicolson, London.

de Balbín Behrmann, R., Alcolea Gonzalez, J.J., 1994. Arte paleolítico de la meseta española. Complutum 5, 97-138.

de Balbín Behrmann, R., Alcolea Gonzalez, J., Santonja, M., Perez Martin, R., 1991. Siega Verde (Salamanca). Yacimiento artístico paleolítico al aire libre. Del paleolítico a la historia. Museo de Salamanca, Salamanca. 33-48.

Bednarik, R.G., 1992. A new method to date petroglyphs. Archaeometry 34, 279-291.

Bednarik, R.G., 1995. The age of the Côa valley petroglyphs in Portugal. Rock Art Research 12, 86-103.

Bednarik, R.G., 2003. First microerosion calibration curve for Iberia. ARKEOS Perspectivas em Diálogo 14, 73-90.

Bednarik, R.G., 2009. Experimental colorimetric analysis of petroglyphs. Rock Art Research 26, 55-64.

Casado Lopez, M.P., 1977. Los signos en el arte Paleolítico de la Península Ibérica. In: Monografías Arqueológicas 20 Zaragoza.

Clottes, J., 1995. Palaeolithic petroglyphs at Foz Côa, Portugal. International Newsletter on Rock Art 10, 2.

Easterbrook, D.J., 1999. Surface Processes and Landforms, second ed. Prentice Hall, Upper Saddle River, NJ.

Finnie, I., 1980. The mechanisms of erosive wear in ductile metals, corrosionerosion behavior of materials. In: Natesan, K. (Ed.), Special Volume, Metallurgical Society of AIME, pp. 118-126.

Foley, M.G., 1980. Bed-rock incision by streams. Geological Society of America Bulletin, Part II 91, 2189-2213.

Graf, W.H., 1977. Hydraulics of Sediment Transport. McGraw-Hill, New York.

Hartshorn, K., Hovius, N., Dade, W.B., Slingerland, R.L., 2002. Climate-driven bedrock incision in an active mountain belt. Science 297, 2036-2038.

Hansen, B.S., 1997. From hell to inferno. Rock Art Research 14, 51-53.

Jorge, S.O., Jorge, V.O., de Almeida, C.A.F., Sanches, M.J., Soeiro, M.T., 1981. Gravuras rupestres de Mazouco (Freixo de Espada à Cinta). Arqueología 3, 3-12.
Martín Santamaría, E., Moure Romanillo, J.A., 1981. Un grabado de estilo paleolítico de Domingo Garcia (Segovia). Trabajos de Prehistoria 38, 97-105.

Martínez, J., 1986/87. Un grabado paleolítico al aire libre en Piedras Blancas (Escullar, Almería). Ars Praehistórica 5/6, 49-58.

Montgomery, D.R., 2004. Observations on the role of lithology in strath terrace formation and bedrock channel width. American Journal of Science 304, 454-476.

Ripóll Lopez, S., Muncio González, L.J., 1994. Un grand ensemble d'art rupestre paléolithique de plein air dans la Meseta espagnole. International Newsletter on Rock Art 7, 2-5.

Ripoll, S., 1997. Comment on R.G. Bednarik, 'Rock art as reflection of conditional visual perception'. Cambridge Archaeological Journal 7, 261.

Reusser, L., Bierman, P., Pavich, M., Larsen, J., Finkel, R., 2006. An episode of rapid bedrock channel incision during the last glacial cycle, measured with ${ }^{10} \mathrm{Be}$. American Journal of Science 306, 69-102.

Sklar, L., Dietrich, W.E., 1998. River longitudinal profiles and bedrock incision models: stream power and the influence of sediment supply. In: Tinkler, K.J., Wohl, E.E. (Eds.), Rivers over Rock: Fluvial Processes in Bedrock Channels. Geophysical Monograph 107. American Geophysical Union, Washington, D.C., pp. 237-260.

Snyder, N.P., Whipple, K.X., Tucker, G.E., Merritts, D.J., 2000. Landscape response to tectonic forcing: digital elevation model analysis of stream profiles in the Mendocino triple junction region, northern California. Geological Society of America Bulletin 112 (8), 1250-1263.

Snyder, N.P., Whipple, K.X., Tucker, G.E., Merritts, D.J., 2003. Importance of a stochastic distribution of floods and erosion thresholds in the bedrock river incision problem. Journal of Geophysical Research 108 (B2), 2117.

Stock, J.D., Montgomery, D.R., Collins, B.D., Dietrich, W.E., Sklar, L., 2005. Field measurements of incision rates following bedrock exposure: implications for process controls on the long profiles of valleys cut by rivers and debris flows. Geological Society of America Bulletin 117 (1-2), 174-194.

Whipple, K.X., Snyder, N.P., Dollenmayer, K., 2000a. Rates and processes of bedrock incision by the Upper Ukak River since the 1912 Novarupta ash flow in the Valley of Ten Thousand Smokes, Alaska. Geology 28 (9), 835-838.

Whipple, K.X., Hancock, G.S., Anderson, R.S., 2000b. River incision into bedrock: mechanics and relative efficacy of plucking, abrasion, and cavitation. Geological Society of America Bulletin 112 (3), 490-503.

Zilhão, J., 1995. The age of the Côa valley (Portugal) rock-art: validation of archaeological dating to the Palaeolithic and refutation of 'scientific' dating to historic or proto-historic times. Antiquity 69, 883-901.

Zilhão, J., Aubry, T., Carvalho, A.F., Baptista, A.M., Gomes, M.V., Meireles, J., 1997. The rock art of the Côa valley (Portugal) and its archaeological context: first results of current research. Journal of European Archaeology 5, 7-49. 